Article

\title{
Climate Change and Its Possible Impact in Groundwater Resource of the Kankai River Basin, East Nepal Himalaya
}

\author{
Champak Babu Silwal 1,2, Dinesh Pathak ${ }^{2, * \mathbb{D}}$, Drona Adhikari 1,2 ${ }^{\mathbb{D}}$ and Tirtha Raj Adhikari ${ }^{3}$ \\ 1 Department of Geology, Central Campus of Technology, Tribhuvan University, Dharan 56700, Nepal; \\ champak.silwal@cct.tu.edu.np (C.B.S.); drona.adhikari@cct.tu.edu.np (D.A.) \\ 2 Central Department of Geology, Tribhuvan University, Kathmandu 44600, Nepal \\ 3 Central Department of Hydrology and Meteorology, Tribhuvan University, Kathmandu 44600, Nepal; \\ tirtha.adhikari@cdhm.tu.edu.np \\ * Correspondence: dinesh.pathak@cdgl.tu.edu.np; Tel.: +977-9841476041
}

Received: 2 October 2020; Accepted: 18 November 2020; Published: 23 November 2020

\begin{abstract}
Increasing evidence of changing climate patterns is being observed, and the impact of this change on groundwater has a direct impact on the livelihood and economy of the region. The research focuses on the impacts of global temperature increase and changing precipitation on the groundwater resources of part of the Himalayan river system. The spatial and temporal variations of the hydro-meteorological data of the Kankai River Basin in East Nepal were analyzed using non-parametric Mann-Kendall tests and Sen's Slope methods, whereas CanESM2 was used to predict the future precipitation scenarios, and an attempt has been made to evaluate the possible impacts on groundwater systems in the region. The temperature shows a significant warming trend $\left(0.14-0.64{ }^{\circ} \mathrm{C} /\right.$ decade); however, the precipitation trends suggest remarkable variation mostly at higher elevation. The average annual precipitation suggests a decrease of $1.82 \mathrm{~mm} /$ year and a similar decrement has been projected for the future. The groundwater in the region has been influenced by the changing climate and the condition may further be exaggerated by reduced recharge and increased evapotranspiration. This understanding of the impacts and climate scenarios will help the planners with better adaptation strategies, plans, and programs for a better society.
\end{abstract}

Keywords: spatial and temporal variability; projection; CanESM2; precipitation; temperature and discharge; groundwater

\section{Introduction}

Global warming due to the enhanced greenhouse effect is likely to have significant effects on the hydrologic cycle [1], which plays an important role in global water balance. Recently, scientific research has been aimed at exploring the response of water resources to climate change, but the dominant research is focused on surface water [2-7]. However, concern has arisen for the water resource management that recognizes groundwater as an integral part, due to its ability to cope with water scarcity, because of its large storage capacity and lower sensitivity to short-term variability in climatic conditions [8]. Meanwhile, groundwater has responded and will continue to respond to changes in climate, and is critical as the changes are not directly visible or easily replenishable [9].

The spatial and temporal variation in the magnitude and intensity of temperature and precipitation over different regions of the world has been observed as a result of climate change [10]. Apart from the global scenarios, studies also claim that the Himalayan region is the most sensitive among the regions of the same latitude [11], and is experiencing a warming trend higher than the average global rate [12]. The climate and hydrological cycles in the region are driven by the summer monsoon [13]. Studies suggest 
that the summer monsoon in the region is getting weaker, whereas western weather is active [14]. The Himalayan Region, also known as the Water Tower of Asia, has a direct role in the circulation of monsoon during summer, and has direct influence on the regional climate [15]. Within this water tower, Nepal lies in the central extension of the Great Himalayan Belt and is characterized by its unique physiographic and topographic variations within the short North-South span of about 130-260 Km. These spatial variations are responsible for varied climatic conditions within a short range of distance [13]. Similarly, the Intergovernmental Panel on Climate Change (IPCC) has identified the Himalayan Region as an area devoid of long-term quality data on the climate, and the information of its impact. The rugged topography and diverse physiography have been the major problems in establishing and maintaining the networks of meteorological stations. Many stations in Nepal have huge gaps in their data series that lead to questionable assessments, which could not be well-justified [16]. The projection of future climate along the Himalayas suggests an increase in the temperature and extreme precipitation events. Furthermore, in some studies, both temperature and precipitation are predicted to increase in future $[5,7,17-19]$, and a considerable shift in the monthly pattern of temperature and precipitation is evident in many regions [19-22].

Climate change's effect on groundwater is complex and unique, as the direct and indirect impacts have not been effectively explored [23]. Data limitation has limited the exploration regarding the magnitude and direction of change in groundwater due to climate change only [24,25]. The complexity further exacerbates as the predicted trend of precipitation varies spatio-temporally, and is less certain than the predicted temperature pattern. The climate variability, largely the precipitation, has considerably contribution to the vulnerable water resources of the semi-arid and arid region [24]. A human dependency on groundwater is inevitable, and projected to increase because the water supplies become over-stressed due to increasing demands made by over-population and climate change [9]. One study projected that there will be an increase in water scarcity by $20 \%$ due to climate change [26].

The Kankai River Basin (KRB) is a rain-fed perennial river system, and climatic variability is expected to influence the water resources of the region. A change in the trend of water availability is expected to affect the future economy of the region critically. Previously, numerous studies have focused on the impacts of climate change on hydrological and other perspectives $[6,17,18,27]$, while the impacts on hydrogeological regime with regard to changing climatic conditions still remain under-addressed at the regional as well as the local scale. Therefore, the impact studies of climate change on groundwater resources (which have the ability to fulfil the water demand even during the driest period) must be prioritized before the planning of any long-term sustainable developmental goal. This study aims to evaluate the hydro-climatic variability and its possible impacts on groundwater in the KRB, Eastern Nepal. This article presents the result of a trend analysis of hydro-meteorological data (temperature, precipitation, and discharge) for the available time, along with a future projection of the precipitation for different scenarios in order to evaluate the climate change scenarios. The results thus obtained are further validated with the social survey data on climate change and the variability in spring discharge (for the northern hilly areas), as well as water level monitoring data from observation wells along with their projection (for the southern plains). The discussion is further extended with the evaluation of temporal land use/land cover change. The result of the analysis has made it possible to evaluate the impact of climate change on the groundwater regime of the region. The understanding of the impacts can help in identifying needs and guide future research, as well as provide a better strategy for integrated water resource management for agriculture, hydropower generation, and other industrial purposes, along with water-related hazards, which ultimately helps in building resilience to the possible impacts.

\section{Study Area}

The study area "the KRB", is located between $27^{\circ} 06^{\prime}-26^{\circ} 28^{\prime} \mathrm{N}$ and $87^{\circ} 41^{\prime}-88^{\circ} 08^{\prime} \mathrm{E}$ in the easternmost part of the Nepalese Himalayas, and is the rain-fed perennial river system originating from the Mahabharat range, excluding the snow-covered zone. The basin has a total area of $1497 \mathrm{sq} . \mathrm{km}$., 
of which about $40 \%$ lies below $600 \mathrm{~m}$ and only $12 \%$ lies above $2000 \mathrm{~m}$. The elevation varies from $73 \mathrm{~m}$ in the south to $3603 \mathrm{~m}$ in the north (Figure 1). Administratively, the study area covers the most part of the Ilam district and the western part of the Jhapa District. The Kankai River is also the tributary of the Mahananda River Basin of India, which ultimately mixes up with the Ganges. The climate in the study area is predominantly governed by the summer monsoon, extending from June to September. The altitudinal variation within the basin causes the climate to be cold tropical in the northern hills to subtropical in the southern lowlands. The river plays an important role in the production of hydropower and the supply of water for irrigation in the downstream southern plains as well. The study area is most popular for its agriculture and husbandry purpose, and supports the lives of the majority of the community. The groundwater from the mountain aquifer in the form of springs serves as the principal source of water in the northern hilly areas, whereas the shallow and deep tube wells drilled in the unconsolidated quaternary sediments serve as the major source of water in the southern plains.

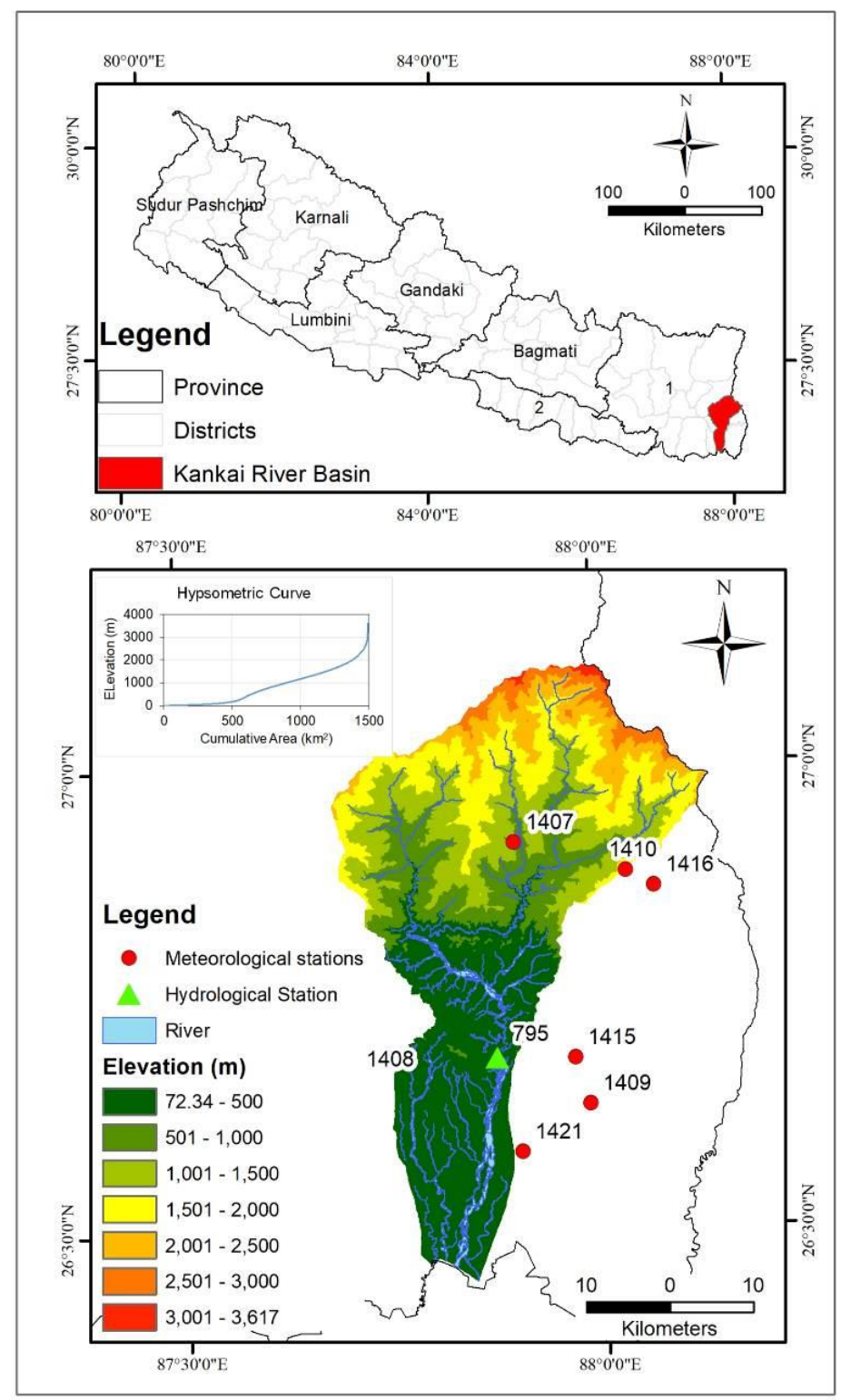

Figure 1. Location map of Kankai River Basin with elevation and distribution of hydrological and meteorological stations (the number 1 and 2 indicates the Province No.). 


\section{Materials and Methods}

\subsection{Observed Hydro-Meteorological Data}

The study uses the observed hydro-meteorological data from the archives of the Department of Hydrology and Meteorology (DHM), Nepal, which is solely responsible for the acquisition, storage, and distribution of this information. Daily hydro-meteorological data within and adjacent to the KRB have been collected for the available period (Table 1, Figure 1).

Table 1. Details of the stations and data used for the analysis ( $\mathrm{P}$ is Precipitation, $\mathrm{T}$ is Temperature and $\mathrm{D}$ is the Discharge).

\begin{tabular}{clcccc}
\hline S. No. & \multicolumn{1}{c}{ Name } & Type & $\begin{array}{c}\text { Latitude } \\
\text { (Deg_Min) }\end{array}$ & $\begin{array}{c}\text { Longitude } \\
\text { (Deg_Min) }\end{array}$ & $\begin{array}{c}\text { Elevation } \\
\text { (m) }\end{array}$ \\
\hline 1 & Ilam Tea Estate (1407) & P, T & $26 \_55$ & $87 \_54$ & 1300 \\
2 & Damak (1408) & $\mathrm{P}$ & $26 \_40$ & $87 \_42$ & 163 \\
3 & Anarmani Birta (1409) & $\mathrm{P}$ & $26 \_38$ & $87 \_59$ & 122 \\
4 & Himali Gaun (1410) & $\mathrm{P}$ & $26 \_53$ & $88 \_02$ & 1654 \\
5 & Sanischare (1415) & $\mathrm{P}$ & $26 \_41$ & $87 \_58$ & 168 \\
6 & Kanyam Tea Estate (1416) & $\mathrm{P}, \mathrm{T}$ & $26 \_52$ & $88 \_04$ & 1678 \\
7 & Gaida (Kankai) (1421) & $\mathrm{P}, \mathrm{T}$ & $26 \_35$ & $87 \_54$ & 143 \\
8 & Mainachuli (795) & $\mathrm{D}$ & $26 \_41$ & $87 \_52$ & 125 \\
\hline
\end{tabular}

The quality of data is the most considerable factor for efficient and accurate analysis, and it sometimes may have bad implications resulting in biased results and analyses [28]. However, it often carries uncertainties, because of the temporal and spatial variability of rainfall measurement, faulty or erroneous instrumentation, the relocation of stations, and sometimes negligence during the measurement of precipitation [29]. The effort of filling up the discontinuous series has been the concern of many studies. The normal ratio method [30] has been used for estimating the missing data for precipitation. The daily observed minimum and maximum temperature also consist of the voids in the series, and have been filled up using the multiple imputation algorithm [31] in XLSTAT 2014. The annual and seasonal data series has been described as mean, standard deviation (SD), coefficient of variation (CV), skewness, and kurtosis.

The seasonal and annual precipitation, temperature, and discharge have been investigated for trend analysis using non-parametric Mann-Kendall tests [32,33] and the Sen's Slope Estimator method [34], which has been widely used in the trend analysis of climate data $[4,35,36]$. Prior to the application of the MK test, the data were tested for Lag 1 autocorrelation. For the Lag 1 autocorrelated data, modification has been applied using XLSTAT 2014 [37] (when there is both a trend and an autocorrelation).

\subsection{Climate Change Projection}

The study used the second generation Canadian Earth System Model (CanESM2) for the projection of future precipitation scenarios, and this has been used effectively in many studies [18,38]. It is a fourth generation Coupled Global Climate Model (CGCM4) developed by the Canadian Center for Climate Modelling and Analysis (CCCma), under the framework of Climate Model Inter-Comparison Project Phase 5 (CMIP5), and it represents the Canadian contribution to the Fifth Assessment Report (AR5) of IPCC.

The General Circulation Model (GCM) in general is unable to resolve the sub-grid and regional climate scenarios, and fails to take into account important regional features such as topography, vegetation, and cloudiness that govern the local climate. As such, it is important to downscale the GCM data from global scale to local scale [18]. The GCM outputs at a global scale, has been statistically downscaled to a point scale using the Statistical Downscaling Model (SDSM version 4.2) [39], and has been used efficiently $[5,17,18,20,40]$. 
The observed data from 1961 to 1990 have been used for the calibration, and from 1991 to 2005 for the validation. Future climate change projection is divided into three periods, namely 2030s (2011-2040), 2060s (2041-2070), and 2090s (2071-2100). For the comparison of observed and downscaled data during calibration and validation, the statistical measures of mean $(\mu)$, standard deviation (SD) and coefficient of determination $\left(R^{2}\right)$ are used. For this study, 20 ensembles were generated using the model and used to examine the precipitation change in the KRB.

To remove any systematic bias in the downscaled precipitation projection data, bias correction using a long-term monthly mean has been applied (Equation (1)) [41].

$$
\mathrm{P}_{\mathrm{BC}}=\mathrm{P}_{\mathrm{SCEN}}\left(\mathrm{P}_{\mathrm{OBS}} / \mathrm{P}_{\mathrm{CONT}}\right)
$$

where, $\mathrm{P}_{\mathrm{BC}}$ is bias-corrected daily precipitation, and $\mathrm{P}_{\mathrm{SCEN}}$ is daily precipitation downscaled using SDSM. $\mathrm{P}_{\mathrm{OBS}}$ is the long-term monthly mean of observed precipitation, while $\mathrm{P}_{\mathrm{CONT}}$ is long-term monthly mean of precipitation simulated using SDSM for the observed period.

\subsection{Groundwater Impact Assessment}

The rocky aquifer from the northern mountain of the study area lacks monitoring data regarding the spring discharge. The gap created by the missing information that is useful to access the change in the mountain's hydrogeological condition was filled by collecting the information through the focus group discussions (FGDs) and the key Informant Interviews (KIIs). A simple questionnaire was used and the survey was conducted in 13 different localities (Figure 2) representing the different sub basins and the ecological regions (the upper, middle and lower reaches) of the KRB. In these localities, the spring water has been used for domestic purposes in the past. The people of the age group 45-65 years, who had been living in the area for at least three decades, were identified as the key informants and interviewed. To observe the monthly variation in water level in the southern plain, the groundwater level monitoring data from different monitoring wells in and adjacent to the area (Figure 2) were collected from the Groundwater Resource Development Board (GWRDB), which is the government authority responsible for groundwater investigation, monitoring and management in Nepal. In addition, the future water level has been projected on the basis of monthly observed data by using the excel function for the forecast of future water level in the different RCPs with respect to the projected annual precipitation. Further, the impact of climate change on groundwater has been compared with the land use/land cover change through the map published by ICIMOD [42,43]. 


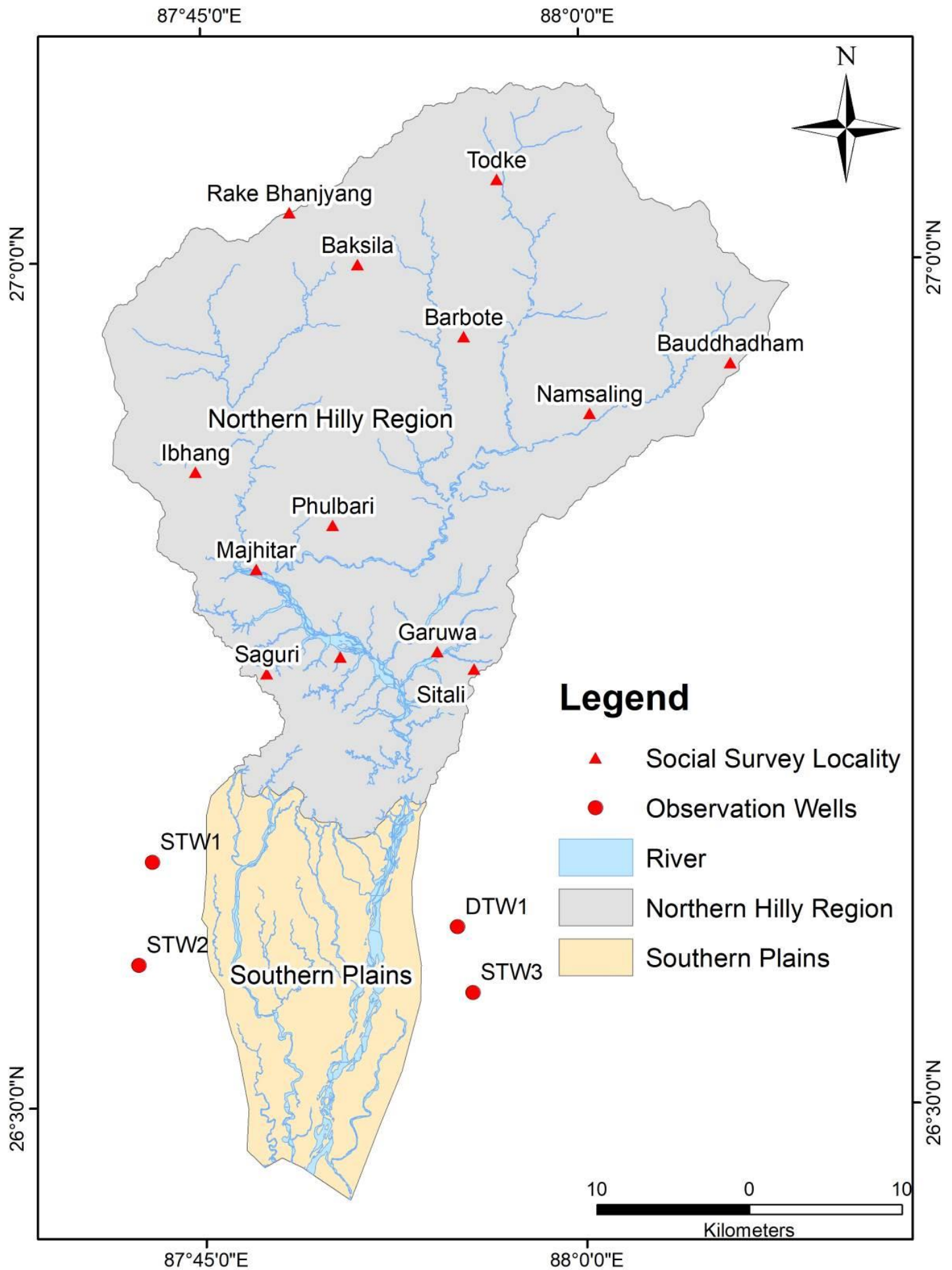

Figure 2. Map showing the distribution of localities for social survey in the northern hilly region and the observation wells (DTW: Deep tube well; STW: Shallow tube well) in the southern plains.

\section{Results}

\subsection{Temperature Trend Analysis}

The minimum and maximum temperature record of the three stations for different times has been analyzed for the average annual and seasonal trends, along with the statistical significance at the $95 \%$ confidence level. The average seasonal and annual statistics from the maximum and 
minimum temperature (Table 2) show that the coefficient of variation (CV) ranges between 0.02 and 0.08 , and 0.06 and 0.18 , respectively, indicating very low variability in maximum temperature as compared to minimum, which is well justified by the standard deviation (SD).

Table 2. Statistical analysis for the maximum (Tmax) and minimum temperature (Tmin) for different stations (1407: 1967-2018, 1416: 1973-2018, and 1421: 1984-2018) (CV: Coefficient of variation and SD: Standard deviation).

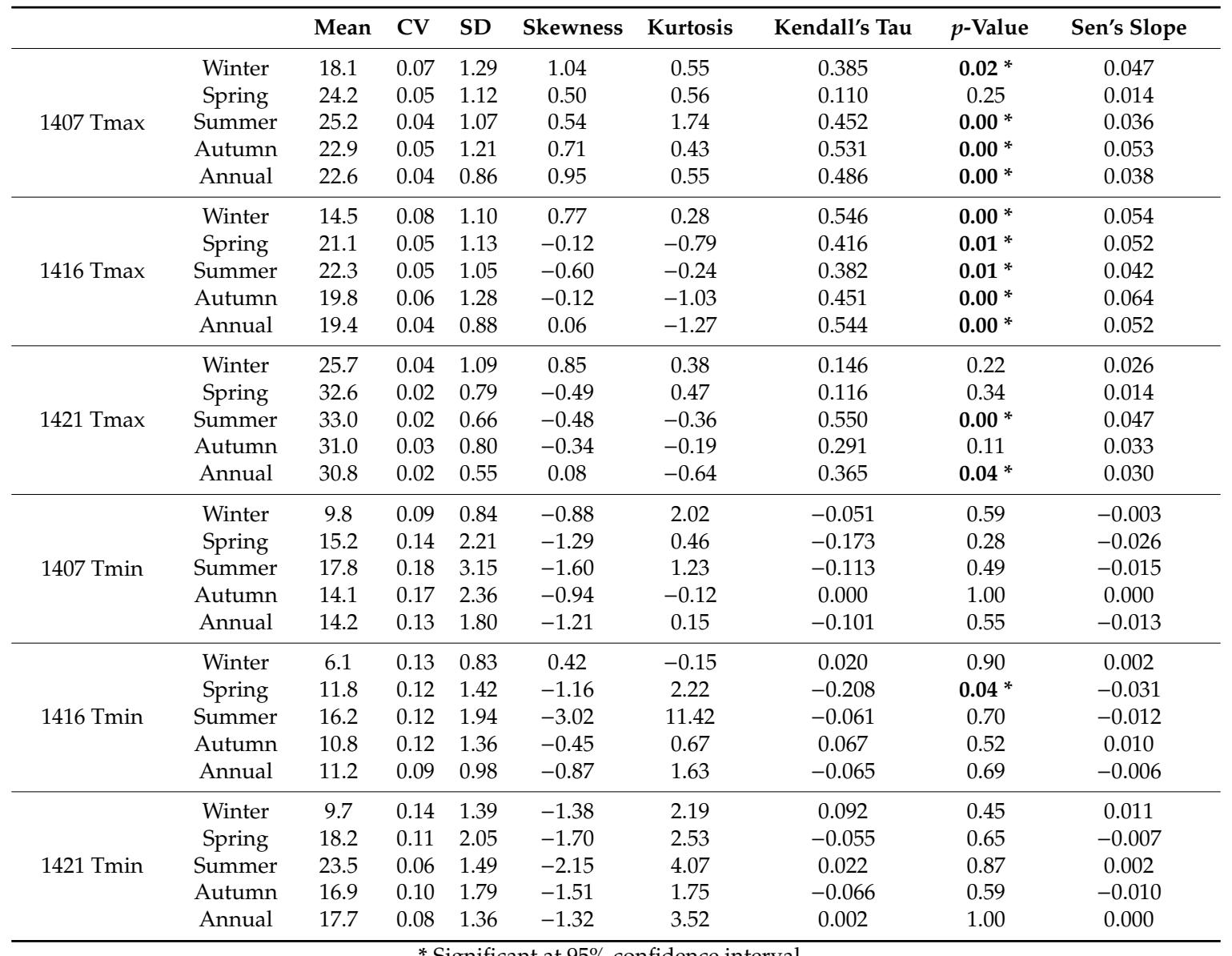

* Significant at $95 \%$ confidence interval.

The trend analysis suggests the changes range from 0.014 to 0.064 for seasonal and annual maximum temperature, and are mostly significant in stations at high elevation (1407 and 1416), whereas the minimum temperature for the same stations shows an insignificant declining trend. Station 1421 witnessed the increasing trend in maximum temperature and is significant only for annual and summer. However, the minimum temperature shows trends that are insignificant with decreases only in autumn and spring. The result depicts that there is a statistically significant increase in annual and most seasonal maximum temperatures, whereas the decreasing trend in minimum temperature is not significant statistically, except for spring at station 1416 (Table 2). The negative trend for minimum temperature can be attributed to the increasing trend of rainfall in other seasons [44].

The comparison between the observed trends in the maximum and minimum temperatures indicates a stronger warming trend (Figure 3). A similar trend has been observed in study of the Karnali River Basin [4], the Marsyangdi River Basin [18], Nepal [45], and the Bagmati River Basin [46]. The trend is positive at lower elevations and negative at higher elevations [45], and something similar has been observed in the present study. The significant positive and insignificant negative trend for the maximum and minimum temperatures, respectively, suggests the possible sensitivity of the area to climate change. 

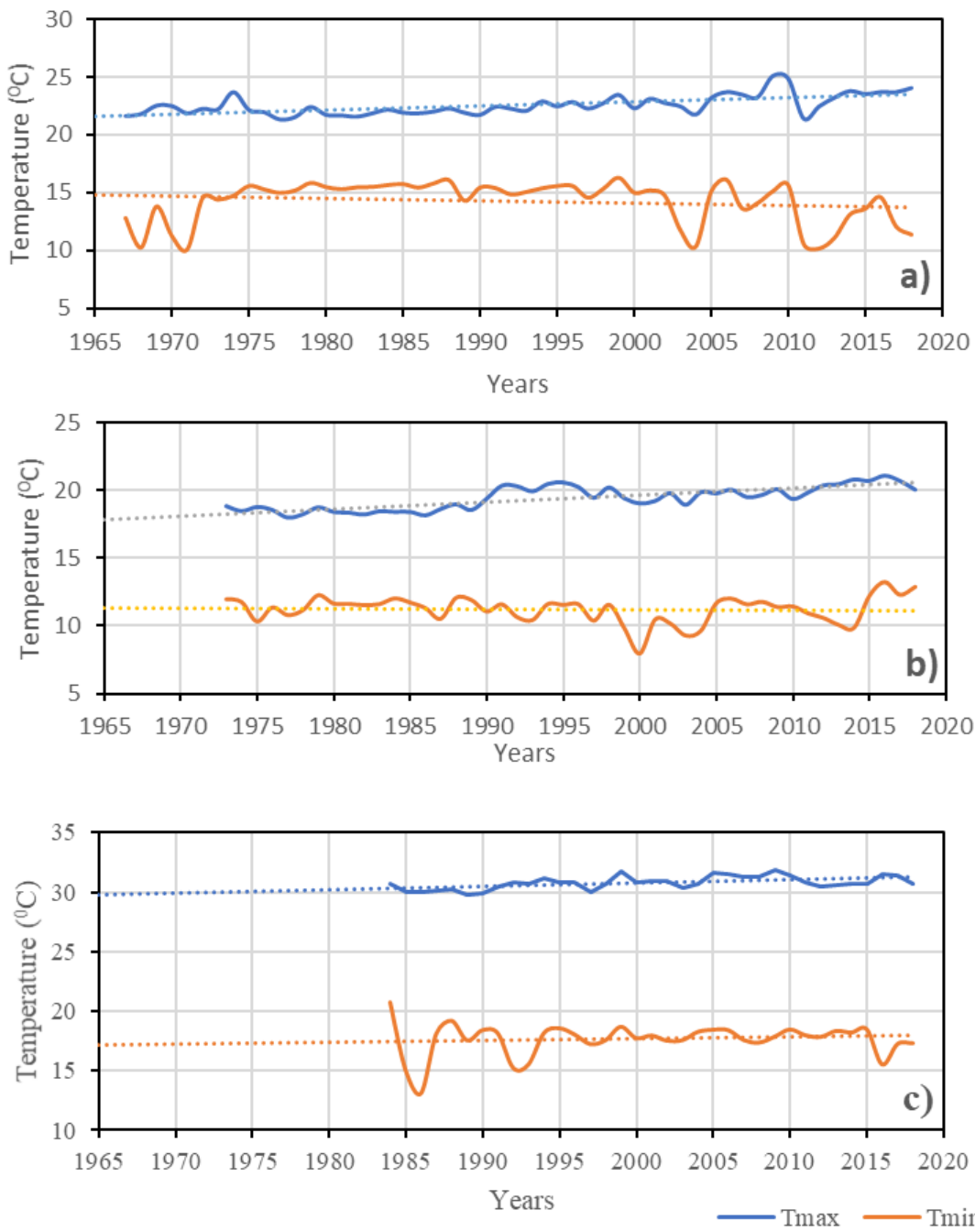

Figure 3. Average annual maximum and minimum temperature for stations (a) 1407, (b) 1416, and (c) 1421. The dotted line shows the trend by linear regression method.

\subsection{Precipitation and Discharge Trend Analysis}

The precipitation records of seven stations for the period 1961-2018 have been assessed in order to delineate the annual and seasonal trends with a $95 \%$ of confidence level, in which the average annual precipitation ranges from $1535 \mathrm{~mm}$ to $2970 \mathrm{~mm}$ (Table 3). The stations at higher elevations show remarkable variation compared to stations at lower elevations (Figure 4). The minimum annual rainfall is received by the station (1407) within the basin that lies in the topographic shadow (Figure 1), causing the local orographic effect resulting in a unique spatial pattern of precipitation as compared with the two other stations. The study also suggests that the higher mountains of Eastern Nepal show significant local relief effects upon precipitation [13,47]. The seasonal pattern of rainfall at different stations shows that the summer rainfall is maximum and highly variable, and is found to be associated with monsoon, whereas the precipitation received in winter is expected to be associated with western weather patterns [48]. The CV for the seasonal and annual precipitation ranges from 0.17 to 1.16 and 0.15 to 0.22 , respectively. This indicates that the seasonal rainfall has remarkable variation in comparison with the annual precipitation. Among the seasons, the precipitation variation is highest in winter $(0.82-1.16)$ and lowest in summer $(0.17-0.26)$. These results are further validated by the obtained values of SD. 
Table 3. Statistical description and trend analysis of seasonal and annual rainfall for time period (1961-2018).

\begin{tabular}{|c|c|c|c|c|c|c|c|c|c|}
\hline & Statistic & Mean & $\mathrm{CV}$ & SD & Skewness & Kurtosis & Kendall's Tau & $p$-Value & Sen's Slope \\
\hline \multirow{5}{*}{1407} & Winter & 28.93 & 0.90 & 26.23 & 0.91 & -0.04 & -0.06 & 0.52 & -0.10 \\
\hline & Spring & 217.49 & 0.34 & 74.12 & 0.32 & -0.62 & 0.02 & 0.80 & 0.22 \\
\hline & Summer & 1211.86 & 0.26 & 312.27 & 0.29 & -0.49 & -0.12 & 0.42 & -3.52 \\
\hline & Autumn & 76.92 & 0.95 & 74.01 & 1.75 & 3.12 & 0.03 & 0.76 & 0.09 \\
\hline & Annual & 1535.36 & 0.22 & 336.33 & 0.47 & 0.16 & -0.13 & 0.15 & -3.91 \\
\hline \multirow{5}{*}{1408} & Winter & 32.12 & 1.07 & 34.71 & 1.64 & 2.97 & -0.07 & 0.46 & -0.10 \\
\hline & Spring & 274.43 & 0.51 & 141.11 & 2.71 & 13.10 & 0.25 & $0.01 *$ & 2.08 \\
\hline & Summer & 1972.32 & 0.23 & 452.06 & 0.45 & -0.82 & -0.15 & 0.09 & -5.30 \\
\hline & Autumn & 132.46 & 0.86 & 114.93 & 1.47 & 2.27 & -0.08 & 0.53 & -0.63 \\
\hline & Annual & 2411.32 & 0.22 & 534.86 & 0.96 & 1.80 & -0.09 & 0.31 & -4.13 \\
\hline \multirow{5}{*}{1409} & Winter & 24.97 & 1.16 & 29.26 & 1.84 & 4.24 & -0.03 & 0.77 & 0.00 \\
\hline & Spring & 259.33 & 0.45 & 117.45 & 0.31 & -0.08 & 0.27 & 0.00 * & 2.74 \\
\hline & Summer & 2034.78 & 0.21 & 420.98 & 0.46 & -0.60 & 0.07 & 0.43 & 2.93 \\
\hline & Autumn & 129.83 & 0.84 & 110.37 & 1.63 & 3.35 & 0.04 & 0.65 & 0.26 \\
\hline & Annual & 2448.91 & 0.20 & 498.04 & 0.47 & -0.59 & 0.11 & 0.20 & 6.20 \\
\hline \multirow{5}{*}{1410} & Winter & 38.06 & 0.82 & 31.41 & 0.91 & 0.21 & -0.04 & 0.67 & -0.10 \\
\hline & Spring & 285.37 & 0.42 & 120.83 & 0.77 & 0.73 & 0.19 & 0.03 * & 1.89 \\
\hline & Summer & 1857.71 & 0.17 & 313.39 & 0.16 & -0.90 & 0.00 & 0.97 & 0.08 \\
\hline & Autumn & 104.71 & 0.86 & 91.16 & 1.36 & 1.38 & 0.00 & 0.97 & 0.03 \\
\hline & Annual & 2286.15 & 0.15 & 338.19 & 0.07 & -0.29 & 0.09 & 0.30 & 2.84 \\
\hline \multirow{5}{*}{1415} & Winter & 29.18 & 1.06 & 31.27 & 1.82 & 4.57 & -0.11 & 0.21 & -0.19 \\
\hline & Spring & 300.18 & 0.40 & 120.22 & 1.13 & 1.33 & 0.20 & 0.03 * & 1.72 \\
\hline & Summer & 2244.78 & 0.19 & 421.48 & -0.18 & -0.30 & -0.03 & 0.74 & -1.13 \\
\hline & Autumn & 144.91 & 0.81 & 118.37 & 1.71 & 3.88 & 0.02 & 0.84 & 0.12 \\
\hline & Annual & 2719.16 & 0.17 & 471.25 & -0.22 & -0.38 & 0.01 & 0.89 & 0.64 \\
\hline \multirow{5}{*}{1416} & Winter & 47.43 & 0.92 & 44.15 & 1.96 & 5.14 & -0.15 & 0.11 & -0.42 \\
\hline & Spring & 360.66 & 0.39 & 142.97 & 0.99 & 0.86 & 0.04 & 0.65 & 0.59 \\
\hline & Summer & 2418.30 & 0.17 & 415.86 & 0.45 & -0.12 & -0.12 & 0.43 & -4.40 \\
\hline & Autumn & 143.61 & 0.88 & 127.21 & 1.68 & 3.14 & -0.06 & 0.54 & -0.36 \\
\hline & Annual & 2970.21 & 0.16 & 469.63 & 0.39 & 0.17 & -0.12 & 0.43 & -5.53 \\
\hline \multirow{5}{*}{1421} & Winter & 30.48 & 0.96 & 29.49 & 1.31 & 1.33 & -0.05 & 0.55 & -0.08 \\
\hline & Spring & 287.97 & 0.41 & 117.81 & 1.37 & 2.93 & 0.16 & 0.08 & 1.40 \\
\hline & Summer & 2174.08 & 0.20 & 445.83 & 0.57 & 0.20 & -0.12 & 0.17 & -4.67 \\
\hline & Autumn & 143.29 & 0.76 & 109.19 & 1.13 & 1.01 & -0.07 & 0.46 & -0.65 \\
\hline & Annual & 2635.91 & 0.19 & 506.35 & 0.56 & 0.04 & -0.08 & 0.37 & -3.65 \\
\hline
\end{tabular}

* Significant at $95 \%$ confidence interval.

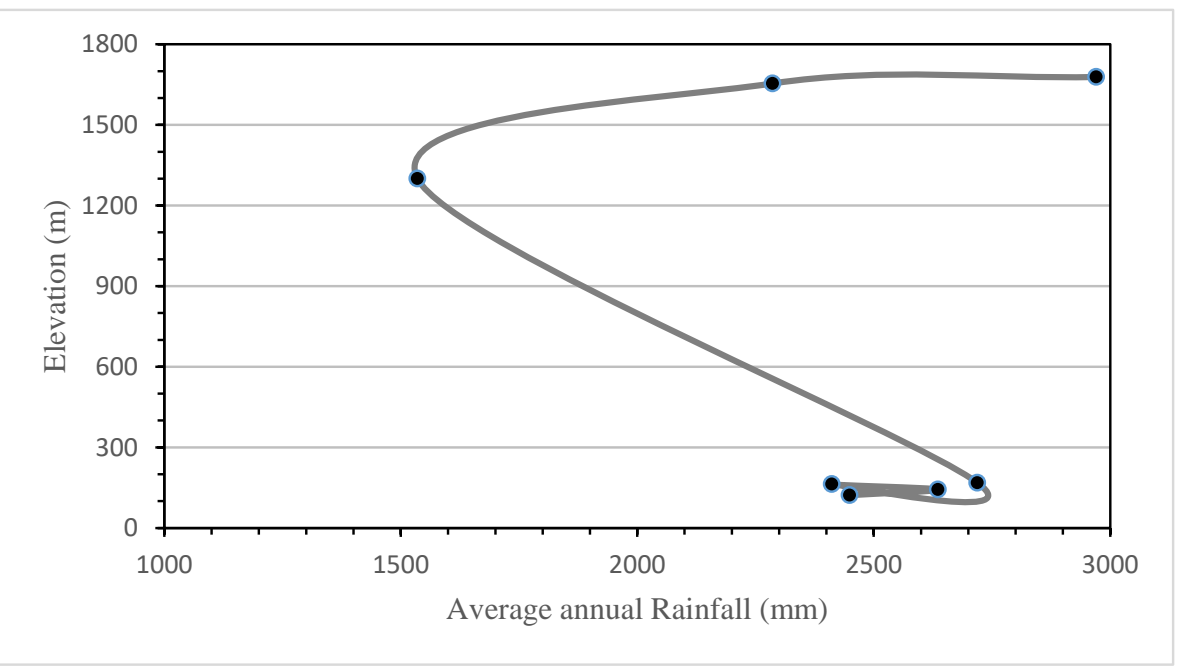

Figure 4. Comparison of annual average rainfall with the elevation of stations. 
The trend analysis of station 1409 only shows the increasing trend for all seasons and the annual precipitation change $(6.20 \mathrm{~mm} / \mathrm{yr})$ is highest among other stations, whereas station 1410 also shows an overall increasing trend except for winter $(-0.10 \mathrm{~mm} / \mathrm{yr})$, which is insignificant. The result matches the findings of [45], which suggest the changes in winter and autumn precipitation are insignificant in the majority of the districts in Nepal. The records for spring of stations 1408, 1409, 1410 and 1415 display increasing trends and are the only values that are statistically significant. The summer, autumn and annual precipitation trends of stations 1409 and 1410, autumn and annual of 1415, and autumn of 1407 exhibit increasing trends. The analysis of the remaining interpreted data demonstrates the decreasing trend of precipitation (Table 3). The results signify the decreasing summer rainfall and increasing rainfall in other seasons, and can be attributed to the weakening summer monsoon [49] and the strengthening of western weather [50], which is well discussed in [14].

The precipitation trend for the individual stations is not uniform across the study area, however the averages of the annual precipitation show a decreasing trend (Figure 5), and a similar result is observed in the precipitation pattern in all parts of Nepal [45] and in the Karnali River Basin [4]. The change in precipitation resembles the heterogeneity of both the increasing and the decreasing trend. Very few results are statistically significant and the case is similar to that of Koshi Basin [3]. The insignificant results for most of the stations have been discussed as associated with the short-term variability in atmospheric pattern, and suggest that it is still unclear [45].

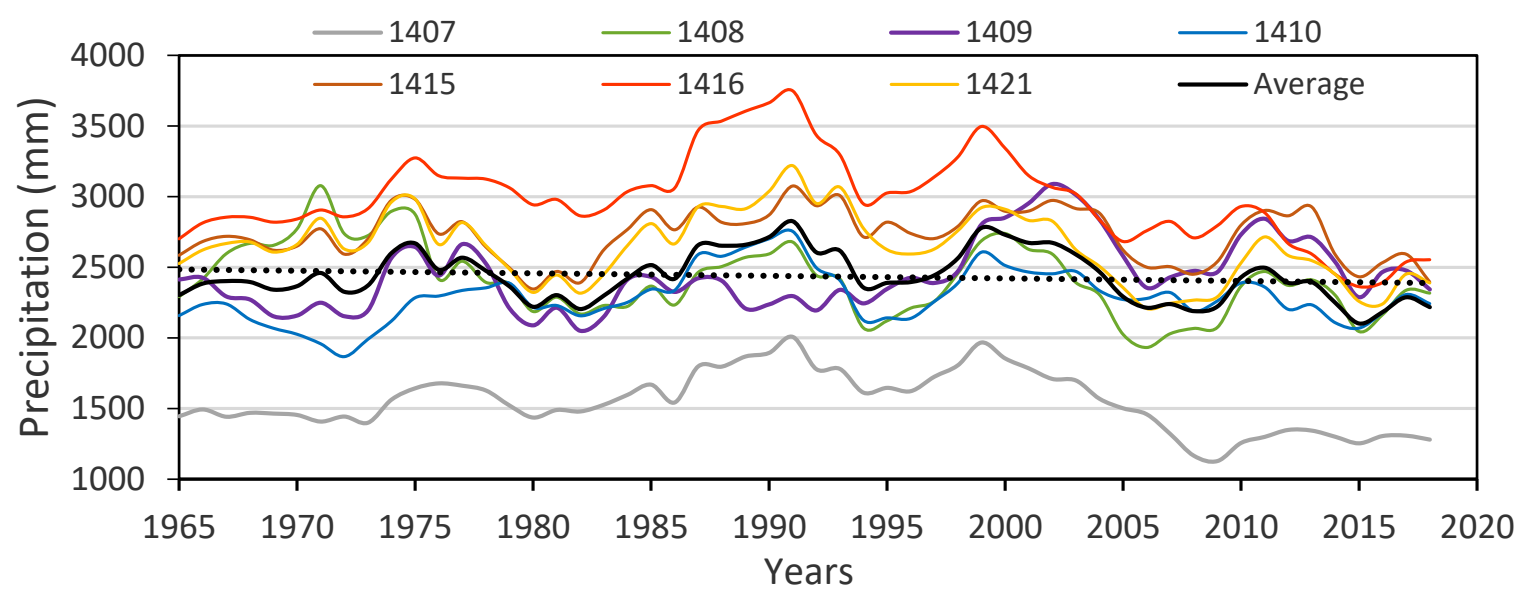

Figure 5. Five-year moving average annual precipitation at different stations and average for the KRB (the dotted line represents the trend line for the average precipitation of the basin).

The discharge record at the outlet of the Kankai River Basin (Mainachuli station, 795) with a catchment area of $1148 \mathrm{sq} . \mathrm{km}$ has been collected for the available period and analyzed for the trend, along with the relation with precipitation pattern at station 1407. Some data from the series have been discarded due to their discontinuous and erroneous nature, and data from 1972-2003 have been taken for analysis. The average monthly discharge suggests the month of September has the highest runoff, followed by August, October, November, December, and so on, until April, where it reaches the minimum. The seasonal and annual mean average discharge suggest that the summer is characterized by peak discharge followed by autumn, winter and spring. The CV ranges from 0.26 to 0.38 , which suggests the variability is not very much. The variability is maximum in spring and minimum in summer. The trend analysis for seasonal and annual average runoff (Table 4) shows insignificant trends for all seasons with increasing trends, except for the summer with the negative trend of -0.23 . 
Table 4. Statistical analysis for seasonal and annual discharge record of Mainachuli stations (795) Kankai River (1972-2003).

\begin{tabular}{ccccccccc}
\hline & Mean & SD & CV & Skewness & Kurtosis & Kendall's Tau & $\boldsymbol{p}$-Value & Sen's Slope \\
\hline Winter & 18.39 & 5.65 & 0.30 & 0.88 & 0.00 & 0.02 & 0.89 & 0.01 \\
Spring & 10.09 & 2.70 & 0.26 & 0.39 & -1.03 & 0.22 & 0.09 & 0.10 \\
Summer & 105.69 & 41.06 & 0.38 & 0.36 & -0.77 & -0.01 & 0.95 & -0.23 \\
Autumn & 94.20 & 34.27 & 0.36 & 0.73 & 1.01 & 0.04 & 0.79 & 0.17 \\
Annual & 58.12 & 17.03 & 0.29 & 0.36 & -0.51 & 0.04 & 0.76 & 0.16 \\
\hline
\end{tabular}

Only precipitation station 1407 lies within and well represents the catchment of the basin, and so the relation between the annual precipitation and discharge has been assessed. The precipitation and discharge, when compared for the same period, both show similar increasing trends (Figure 6). This also reveals that the discharge in the river complies with the precipitation. In addition, the peaks for monthly discharge (September) shows a lag by 2 months with precipitation (July) (Figure 7). A similar lag of 1 month is observed in the Karnali River Basin [4]. The figure depicts the contribution of precipitation to groundwater recharge, which eventually serves as a base flow after the monsoon. The runoff is lower in spring than in winter with minimum rainfall. This suggests that the recharge to groundwater is high during summer and autumn, which provides sufficient runoff through groundwater discharge during winter. This also indicates that the water availability for the downstream area is at a minimum during spring.

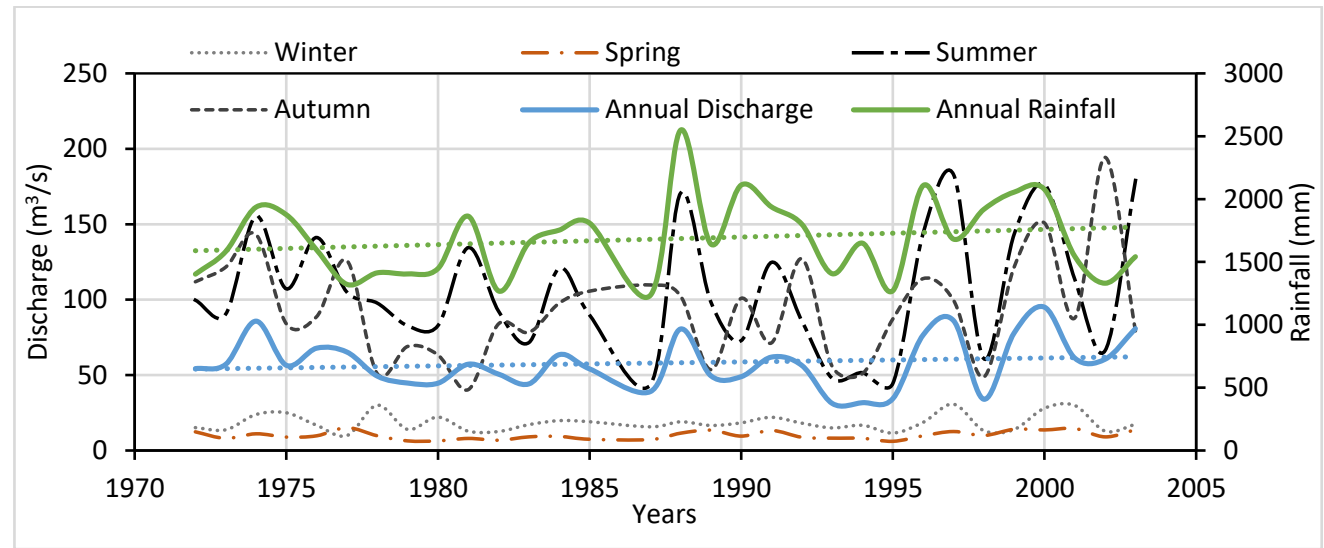

Figure 6. Seasonal and annual average discharge at Mainachuli Station, Kankai River Basin, along with the annual rainfall at station 1407.

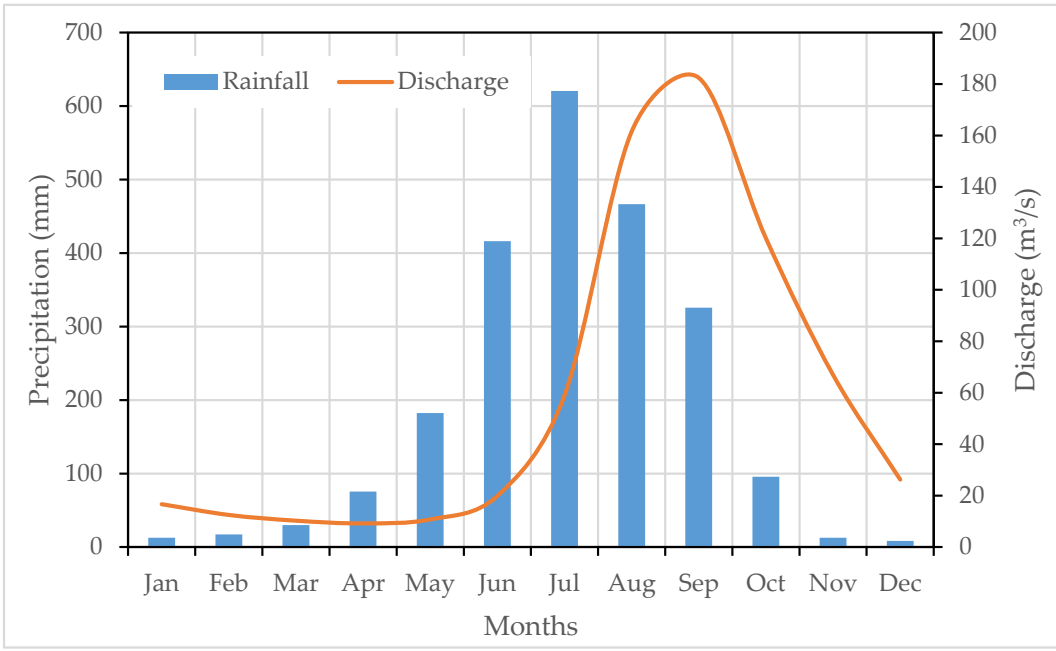

Figure 7. Monthly distribution of precipitaion and average discharge in Kankai River Basin. 


\subsection{Future Precipitation Projection}

The sets of the 26 predictor variables available from the GCM were screened using a combination of partial correlation and $p$-value at a significance level of 0.05 . The predictor's variables with minimum $p$-value and maximum correlation coefficient have been selected as the predictant variables and used for the calibration of the model. The NCEP/NCAR simulated data for the period 1961-2005 have been used for statistical comparison with the observed data.

The summary of the statistical comparison of the observed and simulated monthly precipitations for the calibration period (1961-1990) and the validation period (1991-2005) is presented in Table 5. The coefficient of determination $\left(R^{2}\right)$ for the calibration period ranges from 0.974 to 0.997 , whereas for the validation period it ranges for from 0.92 to 0.98 . This suggests that the simulated data show strong agreement with the observed data. However, the SD is higher, but is close to that of the observed and the reasonable $\mathrm{R}^{2}$, thus the model can be considered significant.

Table 5. Statistical comparison between the observed and simulated monthly precipitation for calibration period (1961-1990) and validation period (1991-2005).

\begin{tabular}{clcccccc}
\hline \multirow{2}{*}{ Stations } & \multicolumn{3}{c}{ Calibration Period } & \multicolumn{3}{c}{ Validation Period } \\
\cline { 3 - 8 } & & Mean & SD & $\mathbf{R}^{\mathbf{2}}$ & Mean & SD & $\mathbf{R}^{\mathbf{2}}$ \\
\hline \multirow{2}{*}{1407} & Observed & 132.55 & 147.77 & 0.997 & 139.01 & 156.89 & 0.92 \\
& Simulated & 129.28 & 140.56 & & 124.38 & 127.84 & \\
\hline \multirow{2}{*}{1408} & Observed & 209.53 & 245.84 & 0.997 & 191.24 & 218.21 & \multirow{2}{*}{0.96} \\
& Simulated & 208.80 & 240.12 & & 179.49 & 201.25 & \\
\hline \multirow{2}{*}{1409} & Observed & 194.11 & 236.70 & 0.997 & 216.11 & 261.51 & 0.92 \\
& Simulated & 195.40 & 230.39 & & 173.19 & 202.58 & \\
\multirow{2}{*}{1410} & Observed & 190.67 & 219.99 & 0.998 & 192.39 & 223.76 & 0.98 \\
& Simulated & 188.70 & 211.79 & & 162.57 & 178.78 & \\
\hline \multirow{2}{*}{1415} & Observed & 226.92 & 272.53 & 0.998 & 231.63 & 274.52 & 0.98 \\
& Simulated & 226.84 & 264.35 & & 209.62 & 244.00 & \\
\hline \multirow{2}{*}{1416} & Observed & 256.97 & 293.94 & 0.998 & 251.44 & 290.62 & 0.98 \\
& Simulated & 251.53 & 288.55 & & 212.11 & 236.91 & \\
\hline \multirow{2}{*}{1421} & Observed & 226.93 & 268.65 & 0.974 & 219.21 & 260.83 & 0.94 \\
& Simulated & 272.38 & 261.54 & & 227.10 & 227.46 & \\
\hline
\end{tabular}

The projected annual average precipitation for the basin (Figure 8) indicates a slight to notable decrease between the representative concentration pathways (RCPs) 2.6 and 4.5, with $0.81 \mathrm{~mm} / \mathrm{yr}$ to $2.06 \mathrm{~mm} / \mathrm{yr}$, respectively, whereas under RCP 8.5 the annual rainfall is expected to rise remarkably, to $2.41 \mathrm{~mm} / \mathrm{yr}$. The change in annual and seasonal precipitation pattern compared to the baseline period (1961-2005) can be visualized from Figure 9. The winter precipitation is expected to increase under all RCPs for all periods. The increase is even the maximum for the RCP 2.6. The spring precipitation is expected to increase progressively under all RCPs, reaching about 50\% at around the 2090s. Meanwhile, the precipitation in autumn can be expected to increase and subsequently decrease up to the 2090s. The summer precipitation, which is the major contributor to annual rainfall, is found to decrease subsequently under RCPs 2.6 and 4.5, whereas for RCP 8.5 the decrement will progressively be minimized until the 2090s. The seasonal rainfall trend cohered well with the projected seasonal changes. The projected annual precipitation, when considered with the elevation, shows a significant decrease in areas with low elevation. The area with elevation higher than $1500 \mathrm{~m}$ shows a minor decrease under $\mathrm{RCP} 4.5$, whereas under RCPs 2.6 and 8.5 the precipitation is expected to increase slightly. 


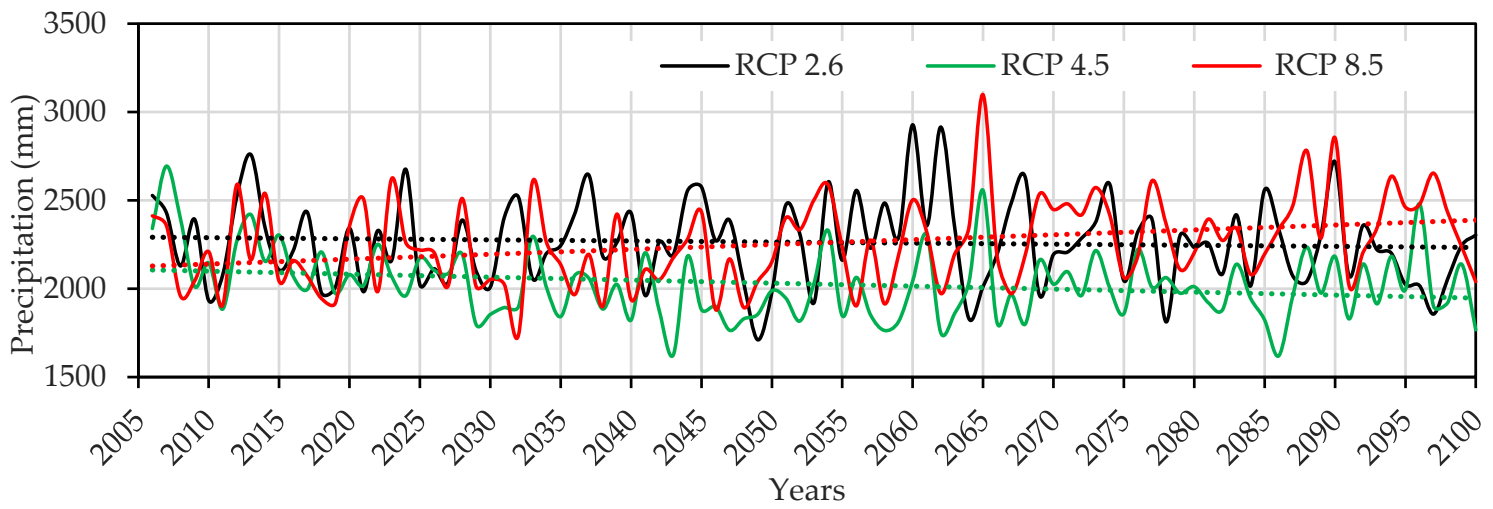

Figure 8. Projected average annual precipitation for the basin under three RCPs.

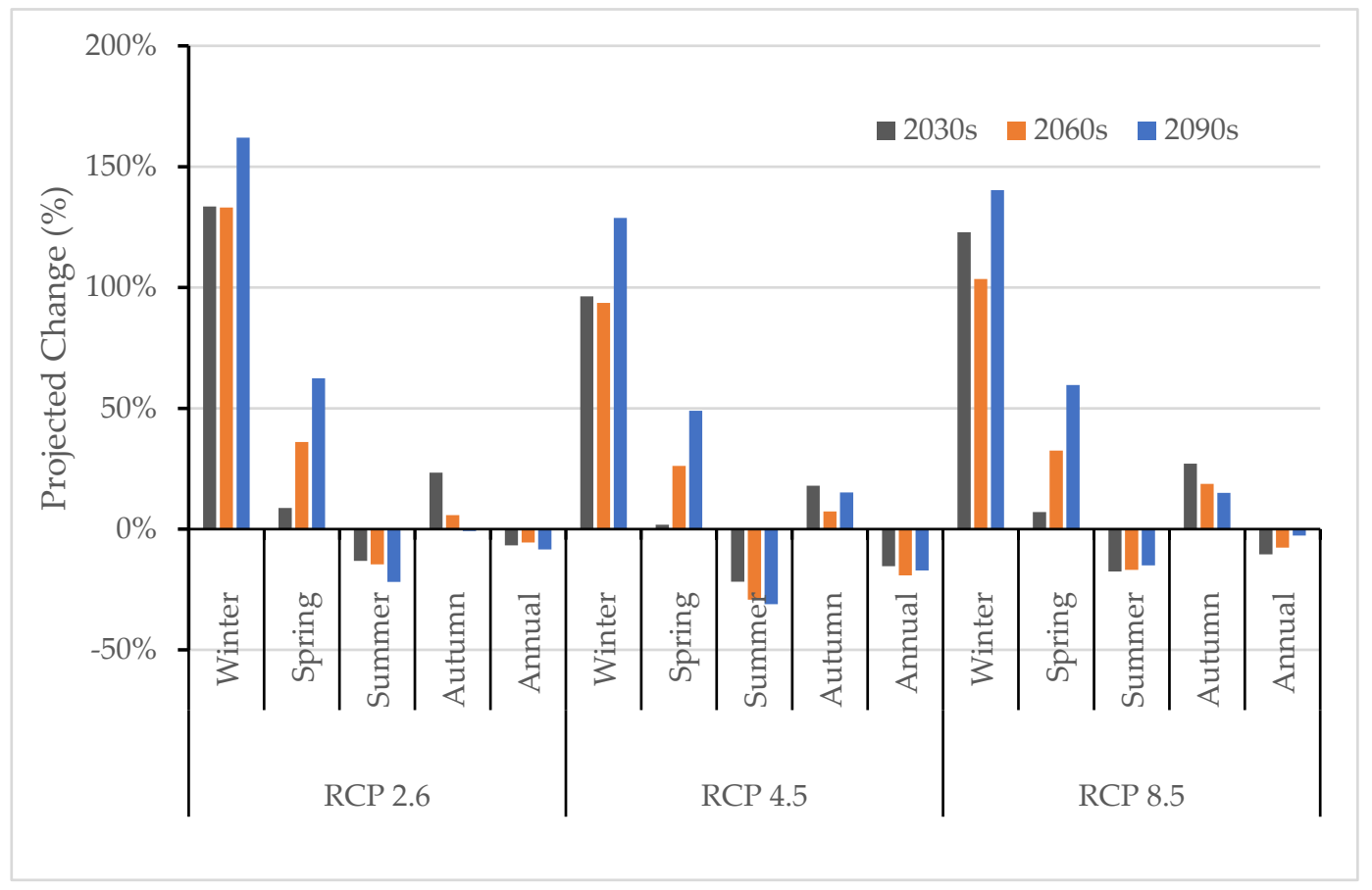

Figure 9. Seasonal change in projected precipitation for the basin compared to the baseline period (1961-2005).

\subsection{Impact on Groundwater Resources}

The result from the social surveys in 13 different localities in the northern hilly region (Figure 2) indicate that the precipitation pattern in the area is changing in terms of intensity and duration. The majority of the respondents reported that the low-intensity and long-duration precipitation during the monsoon has changed to high-intensity and shorter-duration precipitation. In addition to the present characteristics of heavy rainfall for short duration, the overall duration of the monsoon is shortening every year. The respondents also emphasized the uncertain but minor rainfall increase during the winter and spring seasons. The impact of the changed precipitation pattern is visibly observed on the groundwater resources, which are the major lifeline for the people residing in the study area. The springs that the communities have been using for decades are gradually depleting, and many of these springs and ponds are reported to be vanishing. Most of the localities are facing the acute problem of water shortages during the spring season, causing the change in water usage behavior. This scenario is found to be even more critical in the lower reaches of the basin with higher numbers of drying springs. The people of this region are compelled to use the water from the minor rivulets for enhancing the capabilities of water supply to the community. There are several drilled wells 
in the southern plain area in and around the study area. The water level in and around the study area has been assessed via the monitoring data from the observation wells. The observation of water level at different observation wells (Figure 2), including a deep well and three shallow wells, shows the depleting water level for the month of May, the driest period of the year (Figure 10), and this is statistically significant only at STW2 and DTW1 (Figure 2) with a 95\% confidence level. Similar trends can be observed during other months of the pre-monsoon seasons. In addition, the future projection of water level shows a significant decrease except, for the Scenarios 2.6 and 4.5 in tube well STW2, which shows an increase in water level (Figure 11). The change is significant at the $95 \%$ confidence level for scenario 4.5 for all wells, while the trends for other scenarios are insignificant. The depleting water table, especially during the dry season, can be attributed to the depleting groundwater recharge due to the changed precipitation pattern, increasing the exploitation of groundwater for domestic and household purposes and other anthropogenic factors. In addition, the increasing abstraction of groundwater for the fulfilment of water demands during the dry season can also be related to the scarcity caused by the prolonged dry period, which ultimately increases evapotranspiration and demands more water. Thus, climate change is expected to exert more pressure on the groundwater resources.
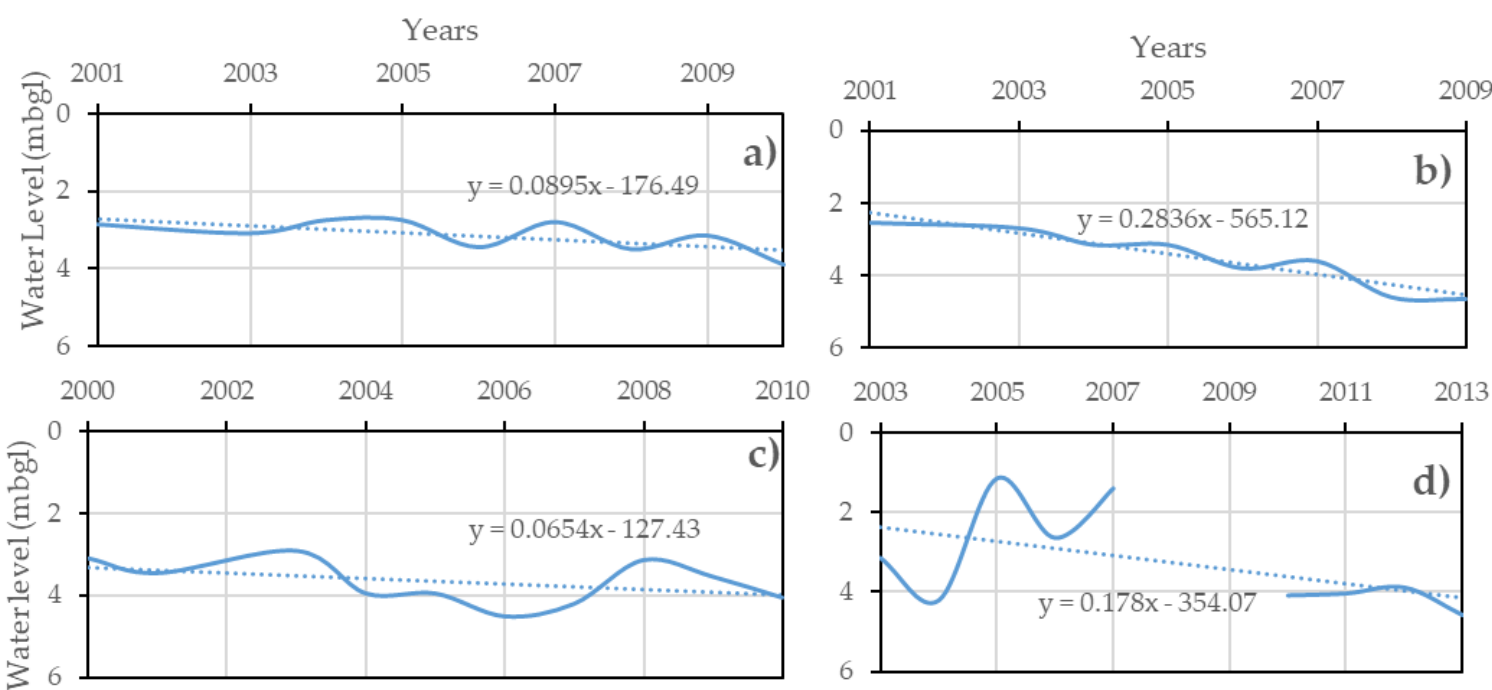

Figure 10. Water level in meters below ground level (mbgl) for the month of May (driest month) in different observation wells around the study area: (a) STW1, (b) STW2, (c) STW3, and (d) DTW1.
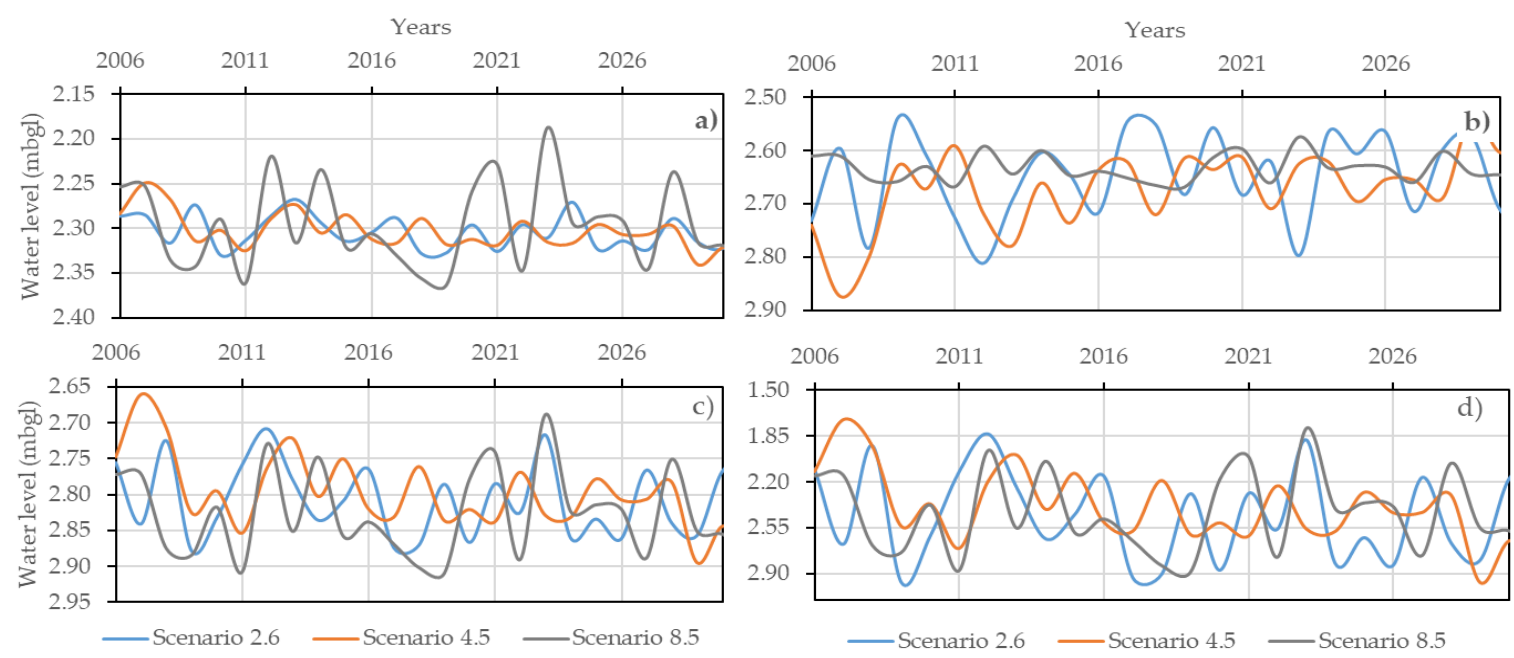

Figure 11. Water level projection with respect to the RCPs for the observation wells (a) STW1, (b) STW2, (c) STW3, and (d) DTW1. 
The evolution of land use/land cover in the basin from 1990 to 2010 shows the decline in the forest area, barren land and shrub land, which is accompanied by a major increase in agricultural land and a minor increase in grassland and settlement (Figure 12). The increase in the water body can be attributed to the impact of the irrigation system developed later, causing the accumulation of sediment and water in the upstream river channels. The declination of natural recharge area (forest, barren land, and shrub land) and the increment of water-consuming land cover elements (agriculture and settlement) seems to create the scenario of increasing water demand and decreasing supply. The scenario is further expected to be worsening with the decreasing water supply caused by the drying sources and changing climate scenarios.

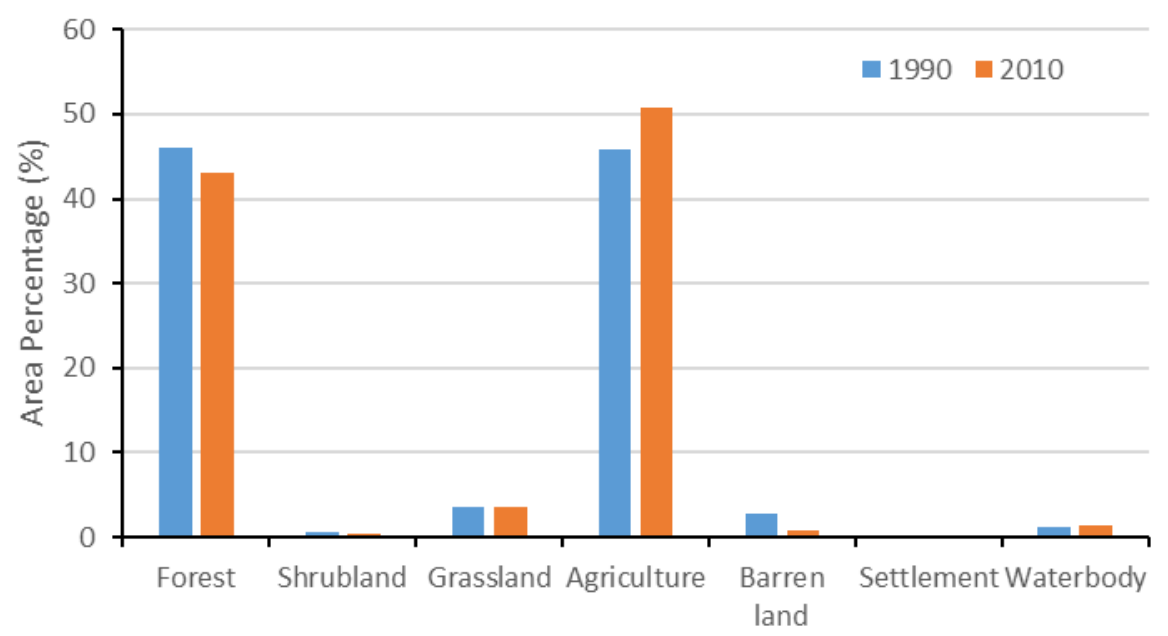

Figure 12. Evolutions in land cover in the basin from 1990 to 2010.

\section{Discussion}

The present analysis reveals that the climate pattern in the region is changing significantly. The climatic variability can be defined as the increase in maximum temperature and decrease in minimum, while the annual precipitation trend shows heterogeneous trends. The trend of annual average discharge well resembles the trend of annual rainfall in the basin. The projected precipitation using CanESM2 indicates that the annual and summer precipitation will decrease in future, whereas the precipitation in other seasons is projected to rise. The limited data on temperature restricts the future projection of temperature; however, the observed trend and predicted temperature do not show much variation in different basins in the region [15]. Hence the temperature trend is supposed to be increasing, as similar to the projection elsewhere $[15,17,18]$.

The impact of climate change on groundwater is complex and unique, as still more has to be understood regarding the direct and indirect response of this valuable water resource. The complexities increase along with the uncertainties in the models used for the predictions and spatiotemporally varying precipitation trends, which are also not significant. However, the temperature trend is significant and is considered critical for shallow aquifers [24]. The change in precipitation and evapotranspiration (induced by the increasing temperature) has a direct impact on recharge and an indirect impact on the discharge or abstraction of groundwater by humans. However, a small change can have larger cumulative effects on recharge, especially in areas with low rainfall [51]. Similar conditions apply in the Kankai River Basin, which has relatively lower rainfall than the surrounding regions. The precipitation trends show high spatial and temporal variability, making it challenging to understand the pattern. This variable pattern can have significant impact on the recharge of groundwater. However, the average annual rainfall in the region shows a decreasing trend (Figure 5), and this can reduce the recharge as well as the runoff, thus limiting the availability of water in dry seasons. The projected increasing precipitation in the spring and winter, when evaluated with the discharge pattern of the KRB, indicates that the water availability in the downstream locality may increase. The driest season will see some increases 
in precipitation to accommodate the scarcity. However, there still exists the chance for rainfall to be absorbed by the soil rather than contributing to runoff. On the other hand, the significant increasing trend in the maximum temperature can increase the evapotranspiration and reduce the runoff [52], and also enhances the loss of soil moisture, creating intense droughts and the depletion of shallow aquifers. The changing climate scenario suggests that the groundwater regime of the region will be highly influenced, and these impacts will have a direct impact on the economy and livelihood of the people of the region. This is also evident from the observation of the declining water level in the southern plains, along with the projected water level for the future and that experienced by the community residing on the northern hilly regions. Further, the change in land cover over time also signifies the changing climatic and groundwater condition. The major impact will be the scarcity of water, creating many social and economic issues. The overexploitation of groundwater to supply the increasing demand will further worsen the condition, making it unmanageable.

\section{Conclusions}

From the above analysis and discussions of the findings of previous studies, the following conclusions are drawn:

1. The maximum temperature in the region is increasing and the minimum temperature is decreasing. The declining trend of minimum temperature is associated with the increasing trend of rainfall in those seasons.

2. The precipitation pattern in the region is unique and is influenced by the orographic effect. The spring precipitation is increasing and the summer is decreasing in most of the stations. The summer monsoon is getting weaker and will continue until the 2050s, when it eventually starts to increase until the 2090s, whereas the rainfall in other seasons shows varying trends but will increase in the future. The average annual rainfall is decreasing and will continue to decrease in future.

3. The water availability in the region will be highly variable and at a minimum during spring, creating the condition of drought. The discharge will decrease with the decrease in annual precipitation.

4. The groundwater in the Kankai River Basin is likely to be highly influenced by climate change. The impacts could be on the decrease in recharge and runoff and increase in evapotranspiration, and this has been made evident by the observed and projected decrease in water level along with the drying of ponds and springs in the northern hilly region. These impacts will eventually influence the groundwater regime of the region and could further worsen the situation.

This study reveals that the impact of climate change in KRB has already taken place in terms of changing temperature and precipitation. The effect will be pronounced, with changes in climatic and hydrological pattern, which will continue with varying degrees of severity in the future. This will certainly have impacts on the water availability in the downstream region. The impacts could be addressed through adaptation practices, and changes in water usage behavior and cropping patterns.

Author Contributions: Conceptualization, D.P. and C.B.S.; methodology, T.R.A. and C.B.S.; software, D.A.; validation, D.P. and T.R.A.; formal analysis, C.B.S. and D.A.; investigation, C.B.S.; writing-original draft preparation, C.B.S. and D.A.; writing—review and editing, D.P. and T.R.A.; supervision, D.P. and T.R.A.; funding acquisition, C.B.S. All authors have read and agreed to the published version of the manuscript.

Funding: This research was funded by University Grant Commission, Nepal as a PhD Research Support Grant, Grant number PhD-74/75-S\&T-8.

Acknowledgments: The authors acknowledge the support provided by the Central Department of Geology, Tribhuvan University and University Grant Commission (UGC), Nepal, for the research work. The authors also acknowledge the Department of Hydrology and Meteorology (DHM) for the acquisition and distribution of hydro-meteorological data and Groundwater Resources Development Board (GWRDB) for sharing the groundwater monitoring data.

Conflicts of Interest: The authors declare no conflict of interest. The funders had no role in the design of the study; in the collection, analyses, or interpretation of data; in the writing of the manuscript, or in the decision to publish the results. 


\section{References}

1. Houghton, E. IPCC Climate Change 1995: The Science of Climate Change. Contribution of Working Group I to the Second Assessment Report of the Intergovernmental Panel on Climate Change; Cambridge University Press: Cambridge, UK, 1996.

2. Pal, A.B.; Khare, D.; Mishra, P.K.; Singh, L. Trend analysis of rainfall, temperature and runoff data: A case study of rangoon watershed in nepal. Int. J. Stud. Res. Technol. Manag. 2017, 5, 21-38. [CrossRef]

3. Nepal, S. Impacts of climate change on the hydrological regime of the Koshi river basin in the Himalayan region. J. Hydro-Environ. Res. 2016, 10, 76-89. [CrossRef]

4. Khatiwada, K.; Panthi, J.; Shrestha, M.; Nepal, S. Hydro-Climatic Variability in the Karnali River Basin of Nepal Himalaya. Climate 2016, 4, 17. [CrossRef]

5. Khadka, D.; Babel, M.S.; Shrestha, S.; Tripathi, N.K. Climate change impact on glacier and snow melt and runoff in Tamakoshi basin in the Hindu Kush Himalayan (HKH) region. J. Hydrol. 2014, 511, 49-60. [CrossRef]

6. Adhikari, T.R.; Devkota, L.P.; Shrestha, A.B. Climate change scenarios and its impact on water resources of Langtang Khola Basin, Nepal. In Proceedings of the International Association of Hydrological Sciences, Bologna, Italy, 4-6 June 2014; Volume 364, pp. 9-13.

7. Bajracharya, A.R.; Bajracharya, S.R.; Shrestha, A.B.; Maharjan, S.B. Climate change impact assessment on the hydrological regime of the Kaligandaki Basin, Nepal. Sci. Total Environ. 2018, 625, 837-848. [CrossRef]

8. Dragoni, W.; Sukhija, B.S. Climate change and groundwater: A short review. Geol. Soc. Lond. Spec. Publ. 2008, 288, 1-12. [CrossRef]

9. Green, T.R. Linking Climate Change and Groundwater. In Integrated Groundwater Management; Jakeman, A.J., Barreteau, O., Hunt, R.J., Rinaudo, J.-D., Ross, A., Eds.; Springer International Publishing: Cham, Germany, 2016; pp. 97-141.

10. Parry, M.L.; Canziani, O.F.; Palutikof, J.P.; Van Der Linden, P.J.; Hanson, C.E. IPCC Climate Change 2007: Contribution of Working Groups I, II and III to the Fourth Assessment Report of the Intergovernmental Panel on Climate Change; Cambridge University Press: Cambridge, UK, 2007.

11. Beniston, M.; Diaz, H.F.; Bradley, R.S. Climatic change at high elevation sites: An overview. Clim. Chang. 1997, 36, 233-251. [CrossRef]

12. Bolch, T.; Kulkarni, A.; Kääb, A.; Huggel, C.; Paul, F.; Cogley, J.G.; Frey, H.; Kargel, J.S.; Fujita, K.; Scheel, M.; et al. The state and fate of himalayan glaciers. Science 2012, 336, 310-314. [CrossRef] [PubMed]

13. Shrestha, M.L. Interannual variation of summer monsoon rainfall over Nepal and its relation to Southern Oscillation Index. Meteorol. Atmos. Phys. 2000, 75, 21-28. [CrossRef]

14. Yao, T.; Thompson, L.; Yang, W.; Yu, W.; Gao, Y.; Guo, X.; Yang, X.; Duan, K.; Zhao, H.; Xu, B.; et al. Different glacier status with atmospheric circulations in Tibetan Plateau and surroundings. Nat. Clim. Chang. 2012, 2, 663-667. [CrossRef]

15. Shrestha, A.B.; Wake, C.P.; Mayewski, P.A.; Dibb, J.E. Maximum Temperature Trends in the Himalaya and Its Vicinity: An Analysis Based on Temperature Records from Nepal for the Period 1971-1994. J. Clim. 1999, 12, 2775-2786. [CrossRef]

16. Salerno, F.; Guyennon, N.; Thakuri, S.; Viviano, G.; Romano, E.; Vuillermoz, E.; Cristofanelli, P.; Stocchi, P.; Agrillo, G.; Ma, Y.; et al. Weak precipitation, warm winters and springs impact glaciers of south slopes of Mt. Everest (central Himalaya) in the last 2 decades (1994-2013). Cryosphere 2015, 9, 1229-1247. [CrossRef]

17. Babel, M.S.; Bhusal, S.P.; Wahid, S.M.; Agarwal, A. Climate change and water resources in the Bagmati River Basin, Nepal. Theor. Appl. Climatol. 2013, 115, 639-654. [CrossRef]

18. Khadka, D.; Pathak, D. Climate change projection for the marsyangdi river basin, Nepal using statistical downscaling of GCM and its implications in geodisasters. Geoenvironmental Disasters 2016, 3, 15. [CrossRef]

19. Singh, D.; Gupta, R.D.; Jain, S.K. Assessment of impact of climate change on water resources in a hilly river basin. Arab. J. Geosci. 2015, 8, 10625-10646. [CrossRef]

20. Pervez, M.S.; Henebry, G.M. Projections of the Ganges-Brahmaputra precipitation-Downscaled from GCM predictors. J. Hydrol. 2014, 517, 120-134. [CrossRef]

21. Li, H.; Xu, C.Y.; Beldring, S.; Tallaksen, L.M.; Jain, S.K. Water resources under climate change in himalayan basins. Water Resour. Manag. 2015, 30, 843-859. [CrossRef] 
22. Rajbhandari, R.; Shrestha, A.B.; Nepal, S.; Wahid, S. Projection of Future Climate over the Koshi River Basin Based on CMIP5 GCMs. Atmos. Clim. Sci. 2016, 6, 190-204. [CrossRef]

23. Earman, S.; Dettinger, M. Potential impacts of climate change on groundwater resources-A global review. J. Water Clim. Chang. 2011, 2, 213-229. [CrossRef]

24. Kundzewicz, Z.W.; Mata, L.J.; Arnell, N.W.; Doll, P.; Kabat, P.; Jimenez, B.; Miller, K.A.; Oki, T.; Sen, Z.; Shiklomanov, I.A. Freshwater Resources and their Management. In Climate Change 2007: Impacts, Adaptation and Vulnerability. Contribution ofWorking Group II to the Fourth Assessment Report of the Intergovernmental Panel on Climate Change; Parry, M.L., Canzizni, O.F., Palutokof, J.P., van der Linden, P.J., Hanson, C.E., Eds.; Cambridge University Press: Cambridge, UK, 2007.

25. Taylor, R.G.; Scanlon, B.; Döll, P.; Rodell, M.; van Beek, R.; Wada, Y.; Longuevergne, L.; Leblanc, M.; Famiglietti, J.S.; Edmunds, M.; et al. Ground water and climate change. Nat. Clim. Chang. 2013, 3, 322-329. [CrossRef]

26. Sophocleous, M. Climate Change: Why Should Water Professionals Care? Groundwater 2004, 42, 637. [CrossRef] [PubMed]

27. Agarwal, A.; Babel, M.S.; Maskey, S. Estimating the Impacts and Uncertainty of Climate Change on the Hydrology and Water Resources of the Koshi River Basin. In Managing Water Resources under Climate Uncertainty; Springer: Cham, Switzerland, 2015; pp. 105-126. [CrossRef]

28. Burhanuddin, S.N.Z.A.; Deni, S.M.; Mohamed, R.N. Revised Normal Ratio Methods for Imputation of Missing Rainfall Data. Sci. Res. J. 2016, 13, 83-97. [CrossRef]

29. Suhaila, J.; Sayang, M.D.; Jemain, A.A. Revised Spatial Weighting Methods for Estimation of Missing Rainfall Data Jamaludin. Asia-Pac. J. Atmos. Sci. 2008, 22, 93-104.

30. Paulhus, J.L.H.; Kohler, M.A. Interpolation of Missing Precipitation Data. Mon. Weather Rev. 1952, 80, 129-133. [CrossRef]

31. Van Buuren, S. Multiple imputation of discrete and continuous data by fully conditional specification. Stat. Methods Med. Res. 2007, 16, 219-242. [CrossRef]

32. Mann, H.B. Nonparametric tests against trend. Econom. J. Econom. Soc. 1945, 13, 245-259. [CrossRef]

33. Kendall, M.G. Rank Correlation Methods, 4th ed.; Charles Griffin: London, UK, 1975.

34. Sen, P.K. Estimates of the Regression Coefficient Based on Kendall's Tau. J. Am. Stat. Assoc. 1968, 63, 1379-1389. [CrossRef]

35. Akter, S.; Howladar, M.F.; Ahmed, Z.; Chowdhury, T.R. The rainfall and discharge trends of Surma River area in North-Eastern part of Bangladesh: An approach for understanding the impacts of climatic change. Environ. Syst. Res. 2019, 8, 1-12. [CrossRef]

36. Gautam, M.R.; Acharya, K. Streamflow trends in Nepal. Hydrol. Sci. J. 2012, 57, 344-357. [CrossRef]

37. Yue, S. Applicability of prewhitening to eliminate the influence of serial correlation on the Mann-Kendall test. Water Resour. Res. 2002, 38, 1-7. [CrossRef]

38. Shafiq, M.; Ramzan, S.; Ahmed, P.; Mahmood, R.; Dimri, A.P. Assessment of present and future climate change over Kashmir Himalayas, India. Theor. Appl. Climatol. 2019, 137, 3183-3195. [CrossRef]

39. Wilby, R.L.; Dawson, C.W. SDSM 4.2-A decision support tool for th e assessment of regional climate change impacts. In User Manual; 2007; p. 94. Available online: https://sdsm.org.uk/SDSMManual.pdf (accessed on 10 July 2020).

40. Mahmood, R.; Jia, S.; Babel, M.S. Potential impacts of climate change on water resources in the kunhar river basin, Pakistan. Water 2016, 8, 23. [CrossRef]

41. Teutschbein, C.; Seibert, J. Bias correction of regional climate model simulations for hydrological climate-change impact studies: Review and evaluation of different methods. J. Hydrol. 2012, 456-457, 12-29. [CrossRef]

42. ICIMOD. Land Cover of Nepal $1990 . \quad$ Available online: https: //rds.icimod.org/Home/DataDetail?metadataId=20828\&searchlist=True\&fbclid= IwAR26BdZmnoiDVfzNIK9m1xFbvs8fXhoR23mvV31rqYm8LVUJPbE8OnD7OYI (accessed on 20 October 2020).

43. ICIMOD. Land Cover of Nepal 2010. Available online: https://rds.icimod.org/Home/DataDetail?metadataId= 9224\&searchlist=True (accessed on 20 October 2020).

44. Rangwala, I.; Miller, J.R. Climate change in mountains: A review of elevation-dependent warming and its possible causes. Clim. Chang. 2012, 114, 527-547. [CrossRef] 
45. DHM. Observed Climate Trend Analysis in the Districts and Physiographic Regions of Nepal (1971-2014); Department of Hydrology and Meteorology: Kathmandu, Nepal, 2017; ISBN 052159386.

46. Dhital, Y.P.; Tang, Q.; Shi, J. Hydroclimatological changes in the Bagmati River Basin, Nepal. J. Geogr. Sci. 2013, 23, 612-626. [CrossRef]

47. Kansakar, S.R.; Hannah, D.M.; Gerrard, J.; Rees, G. Spatial pattern in the precipitation regime of Nepal. Int. J. Climatol. 2004, 24, 1645-1659. [CrossRef]

48. Palazzi, E.; von Hardenberg, J.; Provenzale, A. Precipitation in the Hindu-Kush Karakoram Himalaya: Observations and future scenarios. J. Geophys. Res. Atmos. 2013, 118, 85-100. [CrossRef]

49. Bingyi, W. Weakening of Indian summer monsoon in recent decades. Adv. Atmos. Sci. 2005, 22, 21-29. [CrossRef]

50. Zhao, H.; Xu, B.; Yao, T.; Wu, G.; Lin, S.; Gao, J.; Wang, M. Deuterium excess record in a southern Tibetan ice core and its potential climatic implications. Clim. Dyn. 2012, 38, 1791-1803. [CrossRef]

51. Green, T.R.; Bates, B.C.; Charles, S.P.; Fleming, P.M. Physically Based Simulation of Potential Effects of Carbon Dioxide-Altered Climates on Groundwater Recharge. Vadose Zone J. 2007, 6, 597-609. [CrossRef]

52. Chiew, F.H.S.; Mcmahon, T.A. Modelling the impacts of climate change on Australian streamflow. Hydrol. Process. 2002, 16, 1235-1245. [CrossRef]

Publisher's Note: MDPI stays neutral with regard to jurisdictional claims in published maps and institutional affiliations.

(C) 2020 by the authors. Licensee MDPI, Basel, Switzerland. This article is an open access article distributed under the terms and conditions of the Creative Commons Attribution (CC BY) license (http://creativecommons.org/licenses/by/4.0/). 